\title{
Ethnic Differences in Risk from Mercury among Savannah River Fishermen
}

\author{
Joanna Burger, ${ }^{1,2 *}$ Karen F. Gaines, ${ }^{3}$ and Michael Gochfeld ${ }^{2,4}$
}

\begin{abstract}
Fishing plays an important role in people's lives and contaminant levels in fish are a public health concern. Many states have issued consumption advisories; South Carolina and Georgia have issued them for the Savannah River based on mercury and radionuclide levels. This study examined ethnic differences in risk from mercury exposure among people consuming fish from the Savannah River, based on site-specific consumption patterns and analysis of mercury in fish. Among fish, there were significant interspecies differences in mercury levels, and there were ethnic differences in consumption patterns. Two methods of examining risk are presented: (1) Hazard Index (HI), and (2) estimates of how much and how often people of different body mass can consume different species of fish. Blacks consumed more fish and had higher HIs than Whites. Even at the median consumption, the HI for Blacks exceeded 1.0 for bass and bowfin, and, at the 75th percentile of consumption, the HI exceeded 1.0 for almost all species. At the White male median consumption, noHI exceeded 1, but for the 95th percentile consumer, the HI exceeded 1.0 almost regardless of which species were eaten. Although females consumed about two thirds the quantity of males, HIs exceeded 1 for most Black females and for White females at or above the 75th percentile of consumption. Thus, close to half of the Black fishermen were eating enough Savannah River fish to exceed HI $=1$. Caution must be used in evaluating an HI because the RfDs were developed to protect the most vulnerable individuals. The percentage of each fish species tested that exceeded the maximum permitted limits of mercury in fish was also examined. Over $80 \%$ of bowfin, $38 \%$ of bass, and $21 \%$ of pickerel sampled exceeded $0.5 \mathrm{ppm}$. The risk methodology is applicable anywhere that comparable data can be obtained. The risk estimates are representative for fishermen along the Savannah River, and are not necessarily for the general populations.
\end{abstract}

KEY WORDS: Risk assessment; fish; fishing; fish consumption; mercury; Savannah River Site

\footnotetext{
${ }^{1}$ Division of Life Sciences, Nelson Biological Laboratory, Rutgers University, Piscataway, NJ.

${ }^{2}$ Environmental and Occupational Health Sciences Institute, and Consortium for Risk Evaluation with Stakeholder Participation, Piscataway, NJ.

${ }^{3}$ Savannah River Ecology Laboratory, University of Georgia, Aiken, SC.

${ }^{4}$ Environmental and Community Medicine, UMDNJ-Robert Wood Johnson Medical School, Piscataway, NJ.

*Address correspondence to Joanna Burger, Division of Life Sciences, 604 Allison Road, Rutgers University, Piscataway, NJ 08854-8082; burger@biology.rutgers.edu.
}

\section{INTRODUCTION}

Fishing is an important aspect of rural culture and tradition in the southeastern United States, where the fishing season extends for many months. ${ }^{(1)}$ Yet it is increasingly clear that contaminants, such as mercury and polychlorinated biphenyls (PCBs), are at sufficiently high levels in some fish and seafood to pose a potential health risk to consumers, ${ }^{(2-6)}$ particularly fetuses, neonates, and developing infants. ${ }^{(7,8)} \mathrm{A}$ 
positive relation has been reported between mercury levels in fish, fish consumption by pregnant women, and deficits in neurobehavioral development in their children. ${ }^{(9)}$ Given that $15 \%$ of the nation's lakes and $4 \%$ of the nation's rivers are under consumption advisories, ${ }^{(10)}$ there is cause for concern. Although there are consumption advisories based on contaminant levels for many lakes and rivers in the United States, ${ }^{(6,10)}$ Canada, ${ }^{(11)}$ and elsewhere in the world, risks must be balanced against the positive nutritional and social benefits of consuming fish. ${ }^{(11-13)}$ The oils in fish are associated with reduced cholesterol levels and lowered rates of cardiovascular disease, as well as higher birth weights. ${ }^{(14-18)}$

Consumption advisories should be based on local consumption patterns and contaminant levels in fish. Yet such information is usually lacking, and advisories are based on national or regional consumption patterns. There are few studies in which site-specific information is available for both contaminants and consumption patterns. In this article, we use sitespecific information on contaminant levels in several species of fish, coupled with site-specific fish consumption data for people fishing along the Savannah River, ${ }^{(19)}$ to examine ethnic differences in risk assessments.

Levels of mercury were analyzed in 10 species of fish that are consumed by people who fish on the Savannah River near the Department of Energy's Savannah River Site (SRS). We focused on mercury levels in fish from this region because South Carolina and Georgia have issued fish consumption advisories for the Savannah River, based mainly on mercury and radionuclides. ${ }^{(20,21)}$

We were particularly interested in examining ethnic difference in risk because there are ethnic differences in number of fish meals consumed, average serving size, and kinds of fish consumed. ${ }^{(19)}$ Also, Black people in both South Carolina ${ }^{(22)}$ and Florida ${ }^{(23)}$ are less likely to know about consumption advisories than Whites, suggesting that it is critical to understand whether they are more at risk from consuming fish. Considering the significant social role that fishing plays in Black communities, ${ }^{(1)}$ understanding potential risk is important to developing an overall risk management strategy.

\section{METHODS OF FISH COLLECTION AND ANALYSIS}

\subsection{Study Areas}

Fish were collected from the Savannah River, which passes along the southern border of the De- partment of Energy's SRS in South Carolina. The SRS $\left(33.1^{\circ} \mathrm{N}, 81.3^{\circ} \mathrm{W}\right)$, a $780-\mathrm{km}^{2}$ former nuclear weapons production and current research facility operated by the U.S. government since the early 1950s, is bounded on the south by the Savannah River, which was used as a source of cooling water for the nuclear reactors when they were functioning. Impoundments on the SRS were used as thermal cooling reservoirs for nuclear production reactors. Mercury inputs included long-range atmospheric transport and deposition; industrial effluent entering the Savannah River, upriver from the SRS; and SRS operations. ${ }^{(24-26)}$ Prior to the construction of the SRS reactor cooling ponds, there was ecosystem contamination of stream and river ecosystems, from radionuclide releases and purging of the spent fuel disassembly basins. ${ }^{(27-30)}$ Fish were collected above, along, and below the SRS from Augusta, Georgia, to the Route 301 bridge, to ensure adequate geographical sampling (Fig. 1).

\subsection{Methods of Mercury Analysis}

Using a 6-m Smith Root Electrofisher boat, 10 species of fish that were commonly caught and eaten by local fishermen were collected (see Table I for species). ${ }^{(31,32)}$ All fish were collected under appropriate collecting permits, with protocol approvals from the University of Georgia Institutional Animal Care and Use Committee (A960205), and Rutgers University Institutional Review Board (87-017). Details on collection, preservation, processing, analytic methods, and quality assurance are provided elsewhere. ${ }^{(33)}$

Fish muscle was digested in ultrapure nitric acid in a microwave. Total mercury was analyzed by cold vapor technique. All concentrations are expressed in parts per million ( $\mathrm{ppm} ; \mu \mathrm{g} / \mathrm{g}$, wet weight). The mercury was not speciated. Quality control procedures included standard dilution curves, spiked samples, standards with known concentrations, and blind replicates. ${ }^{(33)}$

\subsection{Ingestion Assumptions}

Most risk assessments rely on standard exposure scenarios and ingestion rates based on daily ingestion by the U.S. population overall, ${ }^{(34,35)}$ for states, ${ }^{(36)}$ or on the maximum amount people could consume given legal fishing or hunting limits. ${ }^{(37)}$ In this study, however, distributions were available of the consumption patterns of 258 fishermen who were interviewed while they were fishing in the same area where the fish were collected. ${ }^{(19)}$ Interviews were conducted by experi- 


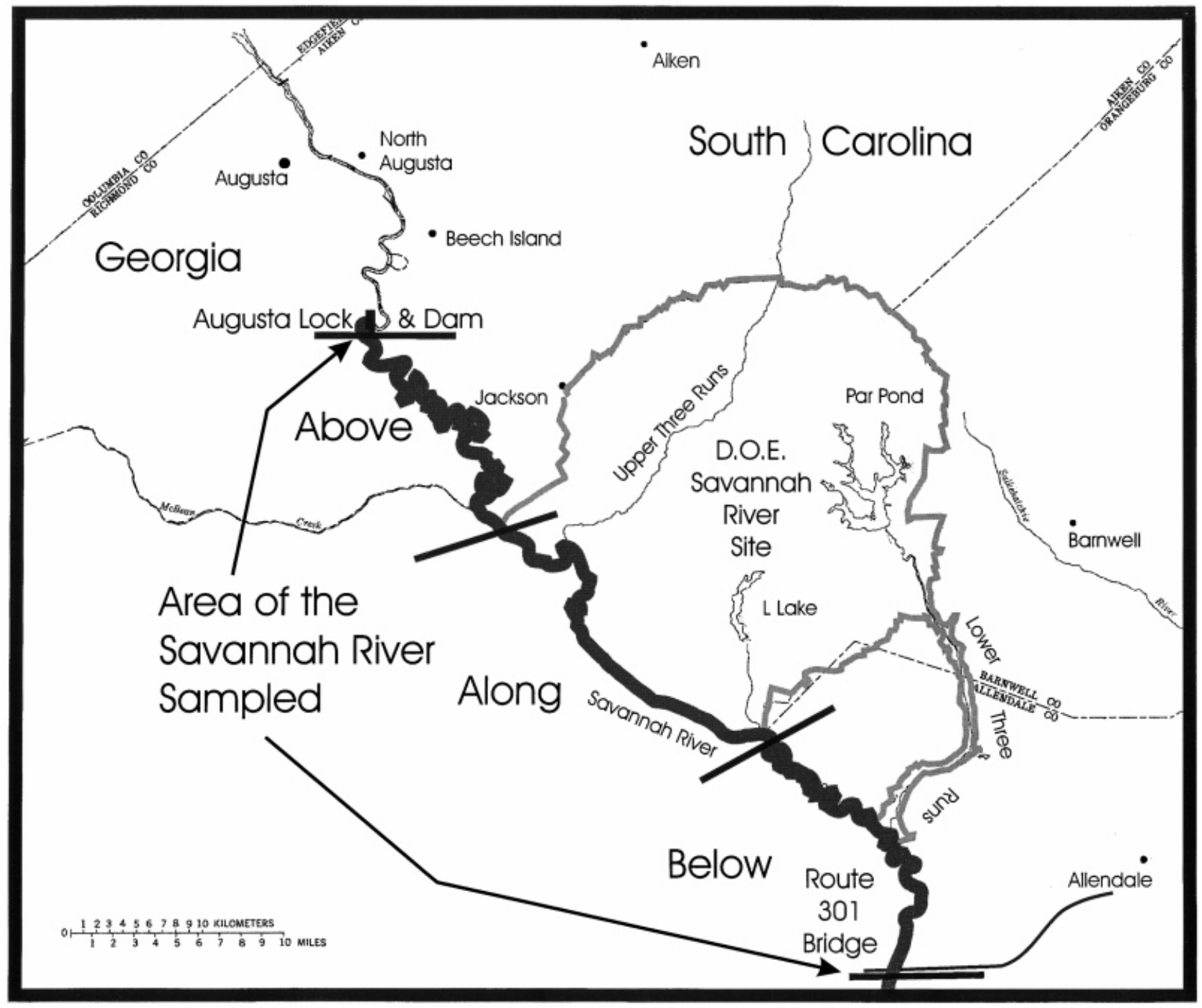

Fig. 1. Map of the Savannah River where fish were collected and fishermen were interviewed, delineating the stretch of river above, along, and below the Savannah River Site. D.O.E. = Department of Energy.

Table I. Mercury Concentrations and Percentage of Each Species Exceeding 0.5 ppm and 1.0 ppm

\begin{tabular}{|c|c|c|c|c|c|c|}
\hline \multirow[b]{2}{*}{ Common name } & \multirow[b]{2}{*}{ Scientific name } & \multirow[b]{2}{*}{$N$} & \multicolumn{2}{|c|}{ Mercury Concentration } & \multirow[b]{2}{*}{$\%>0.5 \mathrm{ppm}$} & \multirow[b]{2}{*}{$\%>1 \mathrm{ppm}$} \\
\hline & & & $M(\mu \mathrm{g} / \mathrm{g})^{a}$ & $S E$ & & \\
\hline Bowfin & Amia calva & 58 & 0.94 & 0.05 & 81 & 45 \\
\hline Largemouth bass & Micropterus salmoides & 48 & 0.46 & 0.04 & 38 & 4 \\
\hline Chain pickerel & Esox niger & 19 & 0.36 & 0.03 & 21 & 0 \\
\hline Yellow perch & Perca flavescens & 39 & 0.28 & 0.02 & 10 & 0 \\
\hline Spotted sucker & Minytrema melanops & 35 & 0.27 & 0.04 & 14 & 3 \\
\hline Black crappie & Pomoxis nigromaculatus & 53 & 0.24 & 0.02 & 9 & 0 \\
\hline Channel catfish & Ictalurus punctatus & 45 & 0.20 & 0.02 & 1 & 0 \\
\hline American eel & Anguilla rostrata & 24 & 0.15 & 0.03 & 8 & 0 \\
\hline Bluegill sunfish & Lepomis macrochirus & 30 & 0.14 & 0.02 & 3 & 0 \\
\hline Red-breasted sunfish & Lepomis auritus & 35 & 0.13 & 0.02 & 6 & 0 \\
\hline
\end{tabular}

${ }^{a} \mu \mathrm{g} / \mathrm{g}$ wet weight $=\mathrm{ppm}$. 
Table II. Parameters of the Distribution of Fish Consumption for 258 Fisherman Interviewed along the Savannah River

\begin{tabular}{lcccc}
\hline & Mean & Median & $\begin{array}{c}\text { 75th } \\
\text { percentile } \\
(\mathrm{g} / \text { day })\end{array}$ & $\begin{array}{c}\text { 95th } \\
\text { percentile } \\
(\mathrm{g} / \text { day })\end{array}$ \\
\hline Black males & 70.1 & 51.8 & 131.5 & 187.9 \\
White males $^{a}$ & 38.4 & 18.8 & 53.4 & 135.3 \\
Black females $^{a}$ & 47.7 & 35.2 & 89.4 & 127.8 \\
White females $^{a}$ & 26.1 & 12.8 & 36.3 & 90.0 \\
\hline
\end{tabular}

Source: Burger et al. ${ }^{(19)}$

${ }^{a}$ Female intake estimated at $68 \%$ of male intake based on Burger $^{(38)}$ for South Carolina families.

enced interviewers from the local area on 54 days spanning most of the fishing season (April 3 to November 22,1997), and were stratified by location. Fish were collected during the same time period. Interviewers approached all fishermen encountered (except those previously interviewed), and 258 of 268 (96\%) agreed to be interviewed. This study had a high response rate because most fishermen enjoyed the opportunity to talk. They were questioned regarding many aspects of their diet, including frequency of fish consumption and average consumption compared with models they were shown. (Additional details are provided in Burger et al. ${ }^{(19)}$ ) Answers to these questions provided information on daily consumption rates of fish (Table II), and on the number of years people fished on the Savannah River. It should be noted that most of the fishermen interviewed (89\%) were men. ${ }^{(19)}$ However, they stated that their wives and children generally ate fish when they did, albeit in smaller portions. In a survey of people at a sportsmen's event in nearby Columbia, South Carolina, it was established that women's portion sizes were about $68 \%$ that of men. ${ }^{(38)}$

Using these data, two plausible exposure scenarios were constructed: (1) People eat entirely a single species of fish, and (2) People eat a diet with equal representation of all species. The mean mercury concentration for each fish, and the median, 75th, and 95th percentiles of the consumption distribution for Black

Table III. Maximum Permitted Limit (Action Levels) of Methylmercury in Fish for Regulation of Commercial Sale or Transport (in Wet Weight, for Total Mercury) and Allowable Intakes, Including Reference Doses and Minimal Risk Levels

\begin{tabular}{|c|c|c|}
\hline & Level & Source \\
\hline \multicolumn{3}{|l|}{ Action level } \\
\hline \multicolumn{3}{|l|}{ United States } \\
\hline FDA & $1 \mathrm{ppm}$ & FDA, $1987^{(51)}$ \\
\hline EPA & $0.3 \mathrm{ppm}$ & USEPA, 2001 ${ }^{(72)}$ \\
\hline Florida & $0.50 \mathrm{ppm}$ & Lange et al., $1994^{(66)}$ \\
\hline Maine & $0.43 \mathrm{ppm}$ & DiFranco and Mower, $1994^{(52)}$ \\
\hline \multirow[t]{2}{*}{ Minnesota } & $0.5 \mathrm{ppm}$ & Minnesota Department of Health, $1997^{(67)}$ \\
\hline & $0.65 \mathrm{ppm}^{a}$ & Minnesota Department of Health, $1997^{(67)}$ \\
\hline Wisconsin & $0.5 \mathrm{ppm}$ & $\begin{array}{l}\text { Gerstenberger } \text { et al. } 1993^{(73)} \\
\quad \text { Dellinger } \text { et al. } 1994^{(74)}\end{array}$ \\
\hline Australia & $0.5 \mathrm{ppm}$ & Denton and Burdon-Jones, $1996^{(75)}$ \\
\hline Canada & $0.5 \mathrm{ppm}$ & NRC, $1991^{(47)}$ \\
\hline Japan & $0.4 \mathrm{ppm}^{b}$ & Nakagawa et al., $1997^{(76)}$ \\
\hline Spain & $1.0 \mathrm{ppm}$ & Schuhmacher et al., 1994 ${ }^{(77)}$ \\
\hline Sweden & $0.5 \mathrm{ppm}$ & Hylander et al., 1994(78) \\
\hline United Kingdom & $0.5 \mathrm{ppm}$ & Collings et al., $1996^{(79)}$ \\
\hline \multicolumn{3}{|l|}{ Reference dose (RfD) } \\
\hline $\mathrm{EPA} \mathrm{RfD}^{a}$ & $0.1 \mu \mathrm{g} / \mathrm{kg} / \mathrm{day}$ & USEPA, $1995^{(80)}$ \\
\hline EPA former RfD & $0.3 \mu \mathrm{g} / \mathrm{kg} / \mathrm{day}$ (for adults) & USEPA, $1995^{(80)}$ \\
\hline WHO & $0.72 \mu \mathrm{g} / \mathrm{kg} / \mathrm{wk}$ & WHO, $1990^{(81)}$ \\
\hline Canada & $0.2 \mu \mathrm{g} / \mathrm{kg} /$ day & Health Canada $^{(41)}$ \\
\hline FDA & $0.4 \mu \mathrm{g} / \mathrm{kg} /$ day (de facto) & $\mathrm{FDA}^{(63)}$ \\
\hline \multicolumn{3}{|l|}{ Minimal risk level } \\
\hline Methylmercury & $0.3 \mu \mathrm{g} / \mathrm{kg} /$ day & ATSDR, $1999^{(41)}$ \\
\hline
\end{tabular}

Note $:$ FDA $=$ Food and Drug Administration $;$ EPA = Environmental Protection Agency; WHO = World Health Organization; ATSDR = Agency for Toxic Substances and Disease Registry.

${ }^{a}$ For women in childbearing age.

${ }^{b}$ Not enforced for some predatory fish. 
and White fishermen were used (Table II). Risk was examined by calculating the Hazard Index (HI; average daily intake over the Reference Dose [RfD]). Theoretically, the RfD is a dose that can be consumed daily by everyone without adverse harm, and an HI below 1 is generally considered indicative of no elevated risk. Because the RfD includes uncertainty factors to protect unusually sensitive subgroups, it follows that an HI greater than 1 does not indicate that everyone, or indeed anyone, will actually suffer adverse consequences. It does indicate that the target group as a whole is at elevated risk. Two RfDs are considered. The current $\mathrm{RfD}$ of $0.1 \mu \mathrm{g} / \mathrm{kg} /$ day (for pregnant women and infants) and the former RfD of $0.3 \mu \mathrm{g} / \mathrm{kg} /$ day for adults. They are discussed below. In this study, a reference body mass of $60 \mathrm{~kg}$ for women and $70 \mathrm{~kg}$ for men was used. Reference doses and other criteria values are shown in Table III.

\section{RESULTS}

\subsection{Mercury Levels}

The sample size, mean, and standard errors of total mercury concentrations are shown in Table I. There were significant differences in mercury concentrations among fish species (Kruskal-Wallis ANOVA; $p<0.001$ ). Bowfin had the highest levels of mercury, followed by bass and pickerel, with eel and sunfish having the lowest levels. Thus, the risk from consuming fish varied depending on the relative contribution of various species to one's diet. Additional details on mercury levels by location are reported separately. ${ }^{(33)}$ Table I also shows the percentage of fish of each spe- cies that exceeded the action levels of $0.5 \mu \mathrm{g} / \mathrm{g}$ (wet weight) and $1.0 \mu \mathrm{g} / \mathrm{g}$ (see Discussion).

\subsection{Risk from Mercury}

The HI was computed for Black and White adult males (Table IV) and females (Table V) for each fish species, assuming that a person consumed all of their meals of one kind of fish (Table I). The adult RfD of $0.3 \mu \mathrm{g} / \mathrm{kg} /$ day for males and the current RfD of 0.1 $\mu \mathrm{g} / \mathrm{kg} /$ day for females were used (recognizing that females who are neither pregnant or about to become pregnant could realistically be covered by the adult RfD). Although it is unrealistic to assume $100 \%$ consumption of only one species, it illustrates the range of HIs possible from the different species of fish. Black fishermen who consumed the median amount of fish exceeded the HI $=1$ only for bowfin and bass. However, Black men who consumed fish at the 75th percentile exceeded the $\mathrm{HI}=1$ for all species except for eel and sunfish. For White males at median consumption, noHI was greater than 1 , but at the 95th percentile, HI $>1$ for all species except eel and sunfish. The HI was then examined assuming that both Black and White fishermen consumed the 10 species of fish equally. Black fishermen at the 75th percentile and White fishermen at the 95th percentile experienced an $\mathrm{HI}=2$.

For females, a consumption rate of $68 \%$ that of males, a body weight of $60 \mathrm{~kg}$, and the RfD of $0.1 \mu \mathrm{g} /$ $\mathrm{kg} /$ day were used. Table $\mathrm{V}$ shows that Black females at the median and White females at the 75th percentile exceeded the $\mathrm{HI}=1$ for all fish but eel and sunfish.

Table IV. Hazard Index (HI) for Black and White Male Fishermen at Different Levels of Fish Consumption

\begin{tabular}{|c|c|c|c|c|c|c|}
\hline & \multicolumn{3}{|c|}{ Black fishermen intake } & \multicolumn{3}{|c|}{ White fishermen intake } \\
\hline & Median & $\begin{array}{c}\text { 75th } \\
\text { percentile }\end{array}$ & $\begin{array}{c}\text { 95th } \\
\text { percentile }\end{array}$ & Median & $\begin{array}{c}75 \text { th } \\
\text { percentile }\end{array}$ & $\begin{array}{c}\text { 95th } \\
\text { percentile }\end{array}$ \\
\hline Bowfin & 2.32 & 5.89 & 8.41 & 0.84 & 2.39 & 6.06 \\
\hline Largemouth bass & 1.13 & 2.88 & 4.12 & 0.41 & 1.17 & 2.96 \\
\hline Chain pickerel & 0.89 & 2.25 & 3.22 & 0.32 & 0.92 & 2.32 \\
\hline Yellow perch & 0.69 & 1.75 & 2.51 & 0.25 & 0.71 & 1.80 \\
\hline Spotted sucker & 0.67 & 1.69 & 2.42 & 0.24 & 0.69 & 1.74 \\
\hline Black crappie & 0.59 & $\mathbf{1 . 5 0}$ & 2.15 & 0.21 & 0.61 & $\mathbf{1 . 5 5}$ \\
\hline Channel catfish & 0.49 & 1.25 & 1.79 & 0.18 & 0.51 & 1.29 \\
\hline American eel & 0.37 & 0.94 & 1.34 & 0.13 & 0.38 & 0.97 \\
\hline Bluegill sunfish & 0.35 & 0.88 & 1.25 & 0.13 & 0.36 & 0.90 \\
\hline Red-breasted sunfish & 0.32 & 0.81 & 1.16 & 0.12 & 0.33 & 0.84 \\
\hline All species equally & 0.78 & 1.99 & 2.84 & 0.28 & 0.81 & 2.04 \\
\hline
\end{tabular}

Note: Assumes a 70-kg body weight and an adult reference dose $=0.3 \mu \mathrm{g} / \mathrm{kg} / \mathrm{day}$. Boldface indicates HI $>1$. 
Table V. Hazard Index (HI) for Black and White Female Family Members

\begin{tabular}{|c|c|c|c|c|c|c|}
\hline & \multicolumn{3}{|c|}{ Black women intake } & \multicolumn{3}{|c|}{ White women intake } \\
\hline & Median & $\begin{array}{c}\text { 75th } \\
\text { percentile }\end{array}$ & $\begin{array}{c}\text { 95th } \\
\text { percentile }\end{array}$ & Median & $\begin{array}{c}\text { 75th } \\
\text { percentile }\end{array}$ & $\begin{array}{c}\text { 95th } \\
\text { percentile }\end{array}$ \\
\hline Bowfin & 5.52 & 14.01 & 20.02 & 2.00 & 5.69 & 14.41 \\
\hline Largemouth bass & 2.70 & 6.86 & 9.80 & 0.98 & 2.78 & 7.05 \\
\hline Chain pickerel & 2.11 & 5.37 & 7.67 & 0.77 & 2.18 & 5.52 \\
\hline Yellow perch & 1.64 & 4.17 & 5.96 & 0.60 & 1.69 & 4.29 \\
\hline Spotted sucker & 1.59 & 4.02 & 5.75 & 0.58 & 1.63 & 4.14 \\
\hline Black crappie & 1.41 & 3.58 & 5.11 & 0.51 & 1.45 & 3.68 \\
\hline Channel catfish & 1.17 & 2.98 & 4.26 & 0.43 & 1.21 & 3.07 \\
\hline American eel & 0.88 & 2.24 & 3.19 & 0.32 & 0.91 & 2.30 \\
\hline Bluegill sunfish & 0.82 & 2.09 & 2.98 & 0.30 & 0.85 & 2.15 \\
\hline Red-breasted sunfish & 0.76 & 1.94 & 2.77 & 0.28 & 0.79 & 1.99 \\
\hline All species equally & 1.86 & 4.72 & 6.75 & 0.68 & 1.92 & 4.86 \\
\hline
\end{tabular}

Note: Assumes that women consume $68 \%$ as much as men. Reference doses for pregnant women, women contemplating pregnancy, and infants is $0.1 \mu \mathrm{g} / \mathrm{kg} /$ day. Boldface indicates $\mathrm{HI}>1$.

Although many fish advisories target "women of childbearing age," most women in this category are neither actually pregnant nor likely to become pregnant in the near future. The real target should be pregnant women and women who will become pregnant while consuming these levels of fish. For the majority of women, regardless of age, one does not need to use the RfD of $0.1 \mu \mathrm{g} / \mathrm{kg} /$ day. Accordingly, HIs were calculated for adult females assuming a consumption rate of $68 \%$ of the male rate, body weight of $60 \mathrm{~kg}$, and RfD of $0.3 \mu \mathrm{g} / \mathrm{kg} / \mathrm{day}$ (not shown in tables). Because these relations are constant, the adult female risk is $79 \%$ that of the corresponding male risk or, conversely, females could increase their fish consumption by $25 \%$. However, USEPA considers the $\mathrm{RfD}=0.1$ to protect all people.

\subsection{Consumption Guidelines}

Although the HI is useful for risk assessors and managers in understanding risk, from the perspective of the consumer it is helpful to understand what factors affect risk and how diet can be modified to minimize risk. Table VI shows the impact of meal size and choice of fish on the frequency with which a pregnant woman could consume fish without exceeding an $\mathrm{HI}=$ 1. Thus, one could consume a $4 \mathrm{oz}(113 \mathrm{~g})$ portion of red-breasted sunfish every other day without reach-

Table VI. Mercury Intake by Different Meal Sizes and Species, and Frequency Such Meals Could Be Consumed by Pregnant Women without Hazard Index Exceeding 1

\begin{tabular}{|c|c|c|c|c|c|c|c|}
\hline & \multicolumn{4}{|c|}{ Mercury intake ( $\mu \mathrm{g} / \mathrm{meal})$} & \multicolumn{3}{|c|}{$\begin{array}{l}\text { Intervals (days) between meals } \\
\text { of different sizes }\end{array}$} \\
\hline & $\begin{array}{l}\text { Mean } \\
(\mu \mathrm{g} / \mathrm{g})\end{array}$ & $\begin{array}{c}6 \mathrm{oz} \\
(170 \mathrm{~g}) \\
\text { meal }\end{array}$ & $\begin{array}{c}8 \mathrm{oz} \\
(227 \mathrm{~g}) \\
\text { meal }\end{array}$ & $\begin{array}{c}10 \mathrm{oz} \\
(284 \mathrm{~g}) \\
\text { meal }\end{array}$ & $\begin{array}{c}6 \mathrm{oz} \\
\text { meals }\end{array}$ & $\begin{array}{c}8 \mathrm{oz} \\
\text { meals }\end{array}$ & $\begin{array}{c}10 \mathrm{oz} \\
\text { meals }\end{array}$ \\
\hline Bowfin & 0.94 & 160.7 & 214.3 & 267.9 & 26.8 & 35.7 & 44.7 \\
\hline Largemouth bass & 0.46 & 78.7 & 104.9 & 131.1 & 13.1 & 17.5 & 21.9 \\
\hline Chain pickerel & 0.36 & 61.6 & 82.1 & 102.6 & 10.3 & 13.7 & 17.1 \\
\hline Yellow perch & 0.28 & 47.9 & 63.8 & 79.8 & 8.0 & 10.6 & 13.3 \\
\hline Spotted sucker & 0.27 & 46.2 & 61.6 & 77.0 & 7.7 & 10.3 & 12.8 \\
\hline Black crappie & 0.24 & 41.0 & 54.7 & 68.4 & 6.8 & 9.1 & 11.4 \\
\hline Channel catfish & 0.20 & 34.2 & 45.6 & 57.0 & 5.7 & 7.6 & 9.5 \\
\hline American eel & 0.15 & 25.7 & 34.2 & 42.8 & 4.3 & 5.7 & 7.1 \\
\hline Bluegill sunfish & 0.14 & 23.9 & 31.9 & 39.9 & 4.0 & 5.3 & 6.7 \\
\hline Red-breasted sunfish & 0.13 & 22.2 & 29.6 & 37.1 & 3.7 & 4.9 & 6.2 \\
\hline All species equally & 0.317 & 54.2 & 72.3 & 90.3 & 9.0 & 12.0 & 15.1 \\
\hline
\end{tabular}

Note: Based on a body weight of $60 \mathrm{~kg}$ and a reference dose $=0.1 \mu \mathrm{g} / \mathrm{kg} / \mathrm{day}$. 
ing an $\mathrm{HI}$ of 1 ; a $20 \mathrm{oz}(567 \mathrm{~g})$ portion could be eaten no more than 3 times a month. By contrast, bowfin could be eaten twice a month ( $4 \mathrm{oz}$ portion) or once every 3 months ( $16 \mathrm{oz}$ portion).

Table VI presents this information for meals of different sizes; although it assumes a human body weight of $60 \mathrm{~kg}$, few adults actually weigh $60 \mathrm{~kg}$. Therefore, one could compute the effect of different body weights. It is obvious that if there is a linear relation between body weight and vulnerability, a lighter person could eat fewer meals of any given fish without exceeding the RfD than could a heavier person. Whether this is actually true or an algebraic artifact is not known.

\section{DISCUSSION}

\subsection{Reference Doses}

International and Governmental agencies (e.g., World Health Organization [WHO], U.S. Environmental Protection Agency [USEPA], Food and Drug Administration [FDA], Agency for Toxic Substances and Disease Registry [ATSDR]) develop their own criteria for the amount of a contaminant that can be consumed by individuals without jeopardizing their health. A standard approach is exemplified by the USEPA's RfD calculated from no observed adverse effect levels (NOAELs) or lowest observed adverse effect levels (LOAELS) divided by a variety of uncertainty factors, including the protection of sensitive individuals. Depending on the database from which the NOAEL/LOAEL is selected and the choice of uncertainty factors, agencies may arrive at somewhat different criterion values. In 1985, the USEPA established an RfD of $0.3 \mu \mathrm{g} / \mathrm{kg} /$ day based on paresthesias in adults exposed to $\mathrm{MeHg}$, later revised to $0.1 \mu \mathrm{g} / \mathrm{kg} /$ day, based on delayed walking among Iraqui victims of methylmercury poisoning. ${ }^{(39)}$ Stern $^{(40)}$ calculated an RfD of $0.07 \mu \mathrm{g} / \mathrm{kg} /$ day. ATSDR $^{(41)}$ recently (1999) published a Minimum Risk Level (MRL) for MeHg of $0.3 \mu \mathrm{g} / \mathrm{kg} /$ day, based on the Seychelles study, ${ }^{(42)}$ and USEPA redid its assessment ${ }^{(43)}$ based on the Faroe Island study, ${ }^{(44)}$ although it ended up with the same RfD of $0.1 \mu \mathrm{g} / \mathrm{kg} /$ day. Even within an agency there may be disagreement: the USEPA Integrated Risk Information System (IRIS) database (http://www.epa.gov/iris) lists an RfD of $0.1 \mu \mathrm{g} / \mathrm{kg} /$ day, ${ }^{(43)}$ whereas the USEPA Office of Water has based fish advisories on an oral RfD of $0.06 \mu \mathrm{g} / \mathrm{kg} / \mathrm{day}{ }^{(45)}$

Because of the discrepancy between the USEPA and ATSDR values and the apparent lack of consistency between the Seychelles and Faroes studies, the
National Institute of Environmental Health Sciences convened an expert panel to conduct a detailed review of the methodologies of these studies. The panel concluded that both studies were valid and made recommendations to try to resolve the discrepant findings. ${ }^{(46)}$ Most recently the National Research Council's Committee on the Toxicological Effects of Methylmercury re-examined these studies and validated the USEPA's $\operatorname{RfD}^{(47)}$ based on the positive findings in the Faroes study. In the present study the RfD of $0.1 \mu \mathrm{g} / \mathrm{kg} / \mathrm{day}$ was used when considering neurodevelopmental risks applicable to women who are pregnant or may soon be pregnant and infants. The former adult RfD of $0.3 \mu \mathrm{g} /$ $\mathrm{kg}$ /day was used in considering risks to other adults (including women of childbearing age who do not plan to become pregnant and adolescents).

Although it is generally assumed that neurodevelopmental delay caused by toxic substances results in permanent deficits, it is less clear that paresthesia (usually reversible) in adults represents a significant endpoint; rather they may be a prelude to more serious organomercury poisoning. Additional information on methylmercury poisoning, for example from the Minamata cohort, ${ }^{(48)}$ will continue to illuminate the dose-response relation.

The USEPA RfD is based on methylmercury, whereas the analyses in the present study and in most studies are for total mercury. At least $90 \%$ of the mercury in fish is methylmercury (results vary somewhat with species and analytic method). Our risk estimates were not adjusted for this discrepancy, but doing so would reduce HIs in Tables IV and V by $10 \%$, which would bring a few marginally elevated HIs (1.120 or less) to below 1.0.

\subsection{Recreational versus Subsistence Fishing}

The literature on the risk from self-caught fish is often couched in reference to "recreation" and "subsistence" hunting and fishing. ${ }^{(37,49)}$ We suggest that the dichotomy between recreational and subsistence fishing is arbitrary and clouds the issue of risk. From a risk assessment perspective, what matters is how much fish of which species is consumed, and their contaminant loads, regardless of whether the fish are self-caught, gifts, or obtained commercially. Whether people are fishing for fun and eating those fish, or are fishing because it is their only source of protein is not relevant to the risk they incur, although it is clearly relevant to a risk management strategy. ${ }^{(22)}$ As Toth and Brown $^{(1)}$ argue, people fish for a variety of reasons, and understanding this complexity is essential for the development of risk management. 
Asking the question of whether there are "subsistence fishermen" in a region allows one to focus on the economic questions, and on the criterion of how much fish must be consumed to qualify as subsistence, rather than on the health risk from contaminants when consuming different amounts of fish. ${ }^{(5)}$ In 1990, NOAA $^{(50)}$ estimated that there were in excess of 17 million recreational fish harvesters. We suggest that future studies on risk from consuming fish include information on fishing and consumption patterns, the reasons why people fish, and on contaminant levels that will allow for the development of a coherent and consistent risk management plan for lowering the risk to fish consumers.

\subsection{Risks from Consuming Fish}

Although there may continue to be some controversy over the appropriate reference dose for mercury and about the interpretation of ongoing epidemiologic studies, the resulting estimates differ only by a factor of three. We suggest that conservatism with respect to public health would argue for using the lower values, but note also that even the most extreme estimates are within one order of magnitude.

Indeed, several states and countries have accepted more conservative levels (Table I). ${ }^{(51-54)}$ Most agencies seem to agree that people should not regularly consume fish with mercury levels above $0.5 \mathrm{ppm}$, and some states advise that women of reproductive age and children should limit meals when mercury levels are close to $0.2 \mathrm{ppm}$, and should not eat any fish over $0.65 \mathrm{ppm} .{ }^{(52,54)}$ On the other hand, various sources suggest that pregnant women should eat oily marine fish because of presumed benefits to fetal development ${ }^{(18)}$ or that any advice that suggests reducing fish consumption is counterproductive. ${ }^{(53)}$

Table I shows the percentage of each fish type collected from the Savannah River that exceeded $0.5 \mathrm{ppm}$ and 1.0 mercury. As is clear, some fish, such as bowfin $(81 \%)$ and bass $(38 \%)$, frequently have values above $0.5 \mathrm{ppm}$, suggesting prudence in consumption. Even a single meal of fish with a mercury level of $2.0 \mathrm{ppm}$ is sufficient to elevate mercury levels in consumers. ${ }^{(55)}$ At the very least, these data warrant providing the fishing public with the necessary information to make informed decisions. As Ginsberg and Toal ${ }^{(55)}$ emphasize, this requires much more extensive fish monitoring data, including individual rather than composited samples and both local and seasonal variability.

We did not encounter any fishermen who preferentially sought or ate bowfin. Bowfin are, however, commonly caught and we were repeatedly told that some fishermen who do not like bowfin will give them to others who are willing to eat them. Black fishermen were observed to be more likely than White fishermen to receive and report consumption of bowfin, thereby enhancing their risk. Largemouth bass is a preferred fish for both Black and White fishermen. However, people do not have analytic data on the contaminants in the fish they actually catch and consume, nor on fish they purchase; hence, information on the distribution of contaminants, such as mercury, in local waters and fish is a necessary surrogate.

The risk from consuming fish derives from the contaminant levels in fish ${ }^{(56)}$ and the amount of fish consumed. ${ }^{(56)}$ However, neither of these factors is straightforward. Fish that are sedentary derive their exposure locally, whereas mobile fish can acquire contaminants at any of the locations they frequent. Local and temporal variations in rainfall and runoff also influence contaminant levels in fish populations at different places and times. The mobility of the fish not only affects contaminant loads, but also the ability of fishermen to catch them in different places at different seasons. There is a seasonal pattern to fish availability that is related to the ecology and behavior of the fish, and the physical characteristics of the river. When the river is high it is relatively difficult to fish, and people can fish from only a few places. Some fish move upriver to spawn during some seasons (spotted sucker), making them easy to catch. Further, some fish are deliberately sought (bass), whereas others are simply caught opportunistically (bowfin, perch, sucker), and not all fish can be caught legally at all times of the year. Finally, there are preferences and dislikes (Whites generally did not eat bowfin and spotted sucker, and some did not eat eel; Blacks did eat these species). Both Black and White fishermen avidly sought bass and sunfish.

This study's risk estimates seem to be representative for fishermen along this stretch of the Savannah River. They are not necessarily representative of the fishermen on the lower Savannah River or other waterways, nor are they typical for the general populations whose fish consumption is much lower.

\subsection{Ethnic Differences and Risk}

In the first scenario, both Black and White fishermen were assumed to eat $100 \%$ of their fish diet from only one species of fish. In the case of bowfin this truly represents a worst-case scenario; however, it is unlikely that any one fisherman would eat only one species of fish, because in the normal course of fishing, they would 
catch other fish. Most fishermen interviewed said that they ate whatever they caught, although some fishermen did not eat particular kinds of fish. Most fishermen said that they froze some fish for later consumption. ${ }^{(19)}$

In a second scenario fishermen were assumed to eat each of the 10 fish species equally. This assumption (based on weight rather than number of fish) did not take into account preferences or avoidances, nor catchability. Both scenarios yielded somewhat similar results, although the exceedances were greater for Black than for White fishermen.

The data indicate that at least $25 \%$ of the Black females (75th percentile) would exceed the $\mathrm{HI}=1$ regardless of the fish they ate. For this group, reducing consumption would be the main strategy. Also $25 \%$ of Black males exceeded the $\mathrm{HI}=1$ for all species except eel and sunfish. For this group, switching to these lower mercury species would be the first strategy.

There are some factors that place certain groups of people at greater risk than others. Several studies have examined the risks from consuming wild-caught fish, and reported that Native Americans, ${ }^{(57,58)}$ Blacks, ${ }^{(1,23,59,60)}$ and Hispanics, ${ }^{(59,60)}$ among others, are more at risk than Whites because of higher fish consumption levels. Based on the 1987 National Health Interview Survey, ${ }^{(60)}$ Whites eat a more varied diet than do Blacks; however, our fishing study showed that Black fishermen eat a greater variety of fish than do White fishermen. ${ }^{(22)}$

In previous studies we found that Blacks consumed significantly more self-caught fish per year than did Whites. ${ }^{(19)}$ Further, the risk from consuming these fish, based on mercury levels alone, indicated that Blacks incur higher risk than Whites, and that at least $25 \%$ of the Blacks interviewed were exceeding the HI regardless of the scenario examined. This confirms Toth and Brown's ${ }^{(1)}$ findings that fishing is very important in Black culture. It also suggests, however, that risk communication should be targeted toward this audience with an eye toward risk reduction.

In other work, Burger et al. ${ }^{(59)}$ established that ethnicity affects information sources, as well as perceptions and compliance. Blacks and Hispanics were less likely to know about any warnings and about the correct warnings than were Whites. But more important, they were less likely to know about the specific effects of mercury on the unborn and young children.

\subsection{Benefits and Risk Reduction}

In addition to social value, fish offer a valuable and healthful source of proteins and lipids, and many studies have extolled these healthful proper- ties. ${ }^{(11-16,53,54,61)}$ Most recently, Ponce et al..$^{(61)}$ have demonstrated that for low-level fish consumers (below $25 \mathrm{~g} /$ day) the benefits of consuming low-mercury fish generally outweigh the harm for the general population but not for the pregnant population. Some of the widely touted cardiovascular benefits of fish consumption may actually be reduced by concomitant mercury exposure. ${ }^{(62)}$

Although it was not the initial intention in this study to examine strategies that could be used for risk management and risk reduction, some general comments are warranted. It is clear from this analysis that people can reduce their risk from mercury by eating some species and avoiding others, particularly by reducing the amount of bowfin and bass they eat. By eating catfish, eel, and sunfish they would be eating fish that average below $0.3 \mathrm{ppm}$ (the range of mercury levels encountered in many commercial fish).

Many fishermen preferred some fish species over others. Either they like the challenge of fishing, the ambience of particular sites, or the "fight" that certain fish display when caught. Moreover, there are preferences regarding taste. Reducing risk does not necessarily entail eating less fish, but may include choosing different species of fish, consuming smaller portions (Table VI), or eating fish less frequently. Overall, providing information in a way that allows people to appreciate the trade-offs among species, and the impact of different frequencies and portion sizes, will allow them to make informed decisions.

One way to think about risk reduction is to determine the number of meals of certain standard sizes that can be eaten per year of each fish type without exceeding an HI of 1 (Table VI). The FDA ${ }^{(63)}$ recommends that people consuming fish with methylmercury levels around $1 \mathrm{ppm}$ should limit intake to $7 \mathrm{oz}$ $(200 \mathrm{~g})$ per week; and for fish with methylmercury levels around $0.5 \mathrm{ppm}$, to $400 \mathrm{~g} /$ week. For a $70 \mathrm{~kg}$ adult this amounts to $0.4 \mu \mathrm{g} / \mathrm{kg} /$ day.

Several other actions can reduce overall exposure to contaminants, including altering cooking methods $^{(64)}$ and selecting smaller rather than larger fish within a species, as older and larger individuals tend to have higher contaminant levels. ${ }^{(65)}$ For example, mercury concentrations in largemouth bass increase as fish increase in size and age. ${ }^{(65,66)}$ This risk assessment does not take into account dose rate, or whether consuming a fixed dose in one meal once a week has the same or a greater effect than consuming the same total amount in smaller daily doses. Some 
states suggest freezing fish to space the fish meals out over a longer time period, and removing the fat to eliminate other contaminants. ${ }^{(67)}$

Although these actions can reduce exposure to contaminants from the consumption of fish, it is clear that effective risk reduction requires providing the public with the kinds of information that help them to make informed decisions, allowing them to select fish and consumption patterns that they consider desirable (acceptable, beneficial). However, even if such information is included in advisories, compliance with consumption advisories may not occur. ${ }^{(22,68)}$ This is, in part, because risk management experts may not understand the specific information needs of the target audience, ${ }^{(68,69)}$ and, in part, because people may choose to ignore the warnings, ${ }^{(22)}$ or may rely on nonofficial sources of information, including their own observations and personal experience.

In the end, options for consumers include consuming different fish species (fewer bowfin and more sunfish), consuming smaller fish, and decreasing portion size and frequency (fewer and smaller portions of fish with greater amounts of mercury). In this regard, size limits (requiring the release of fish below certain lengths), is counterproductive because it encourages the consumption of larger "legal" fish that probably have higher mercury levels.

\subsection{Other Sources and Hazards Affect Risk}

Finally, it should be noted that fish contain other contaminants besides mercury (other heavy metals, organics, radionuclides) ${ }^{(56)}$ that can pose a health risk, and that fish may not be the only source of mercury exposure for some people..$^{(5)}$ Mercury can come from other forms of protein, including commercial products such as farm animals, which are fed fishmeal. ${ }^{(56)}$ The $\mathrm{NRC}^{(47)}$ estimated that the average consumption of mercury from aquatic animals (all fish and shellfish) represents over half of the mercury estimated to be in the diet of Americans. Some drinking water supplies also contain mercury in excess of the maximum allowable concentration of 2 parts per billion.

Although we did not study organic contaminants, there is evidence that bioaccumulative chlorinated compounds, such as dioxins and PCBs, likewise accumulate in larger individuals of large predatory species. Thus, adjusting the diet to minimize mercury intake will have collateral benefits with respect to other toxicants. These PCBs and other organics may interact synergistically with mercury, ${ }^{(70)}$ as was demonstrated in vitro by Bemis and Seegal. ${ }^{(71)}$

\section{ACKNOWLEDGMENTS}

The authors thank C. Dixon, M. McMahon, and S. Shukla for computer assistance; R. Ramos for making the map; T. and R. Shukla for analytical assistance; I. L. Brisbin, Jr. and J. W. Gibbons for logistical support at the Savannah River Site (SRS); and B. D. Goldstein, J. Nelsen, C. Powers, J. Sanchez, A. Stern, A. Upton, C. Warren, and $\mathrm{W}$. Whitaker for comments on the research and manuscript. This research was also influenced by discussions with members of the SRS Citizen's Advisory Board who strongly encouraged the ethnic analysis, and the Center for Disease Control's SRS Health Effects Subcommittee. This research was funded by the Consortium for Risk Evaluation with Stakeholder Participation through the Department of Energy (AI\#DE-FC01-95EW55084, \#DE-FG 2600NT 40938), the National Institute of Environmental Health Sciences (ESO 5022, J. B., M. G.), and Financial Assistance Award \#DE-FC09-96SR18546 from the U.S. Department of Energy to the University of Georgia Research Foundation (K. F. G.). The results, conclusions, and interpretations reported herein are the sole responsibility of the authors, and should not in any way be interpreted as representing the views of the funding agencies.

\section{REFERENCES}

1. Toth, J. F., Jr., \& Brown, R. B. (1997). Racial and gender meanings of why people participate in recreational fishing. Leisure Sciences, 19,129-146.

2. Sparks, P., \& Shepherd, R. (1994). Public perceptions of the potential hazards associated with food production: An empirical study. Risk Analysis 14, 799-808.

3. Horn, E. (1992). Toxics in seafood. Tidal Exchange, 3, 6-7.

4. Agency for Toxic Substances and Disease Registry (ATSDR). (1996). States issue a record number of health advisories. Hazardous Substances Public Health, 6,1-2.

5. Institute of Medicine. (1996). Seafood safety. Washington, DC: National Academy Press.

6. Kamrin, M. A., \& Fischer, L. J. (1999). Current status of sport fish consumption advisories for PCBs in the Great Lakes. Regulatory Toxicology and Pharmacology, 29, 175-181.

7. Ratcliffe, H. E., Swanson, G. M., \& Fischer, L. J. (1996). Human exposure to mercury: A critical assessment of the evidence of adverse health effects. Journal of Toxicology and Environmental Health, 49, 221-270.

8. Weiss, B., \& Elsner, J. (1996). Risk assessment for neurobehavioral toxicity. Environmental Health Perspectives (Suppl. 104), 171-413.

9. Weihe, P., Grandjean, P., Debes, F., \& White, R. (1996). Health implications for Faroe Islanders of heavy metals and PCBs from pilot whales. Science of the Total Environment, 186, 141148

10. U.S. Environmental Protection Agency (EPA). (1996). Update: National listing of fish and wildlife consumption advisories. Cincinnati, Ohio: Author.

11. Wheatley, B., \& Paradis, S. (1996). Balancing human exposure, 
risk and reality: Questions raised by the Canadian aboriginal methylmercury program. Neurotoxicology, 17, 241-250.

12. Kimbrough, R. D. (1991). Consumption of fish: Benefits and perceived risks. Journal of Toxicology and Environmental Health, 33, 81-91.

13. Egeland, G. M., \& Middaugh, J. P. (1997). Balancing fish consumption benefits with mercury exposure. Science, 278, 19041905.

14. Wahlquist, M. L., Lo, C. S., \& Myers, K. A. (1989). Fish intake and arterial wall characteristics in healthy people and diabetic patients. Lancet, 2, 944-946.

15. Hunter, D. J., Kazda, I., Chockalingam, A., \& Fodor, J. G. (1988). Fish consumption and cardiovascular mortality in Canada: An inter-regional comparison. American Journal of Preventive Medicine, 4, 5-11.

16. Anderson, P. D., \& Wiener, J. B. (1995). Eating fish. In J. D. Graham and J. B. Wiener (Eds.), Risk versus risk: Tradeoffs in protecting health and the environment (pp. 104-123). Cambridge, MA: Harvard University Press.

17. Daviglus, M. L., Stamler, J., \& Orencia, A. J. (1997). Fish consumption and the 30-year risk of fatal myocardial infarction. New England Journal of Medicine, 336, 1046-1053.

18. Olsen, S. F., Olsen, J., \& Frische, G. (1990). Does fish consumption during pregnancy increase fetal growth? International Journal of Epidemiology, 19, 971-977.

19. Burger, J., Stephens, W., Shane Boring, C., Kuklinski, M., Gibbons, J. W., \& Gochfeld, M. (1999). Factors in exposure assessment: Ethnic and socioeconomic differences in fishing and consumption of fish caught along the Savannah River. Risk Analysis, 19, 421-431.

20. South Carolina Department of Health and Environmental Control (SCDHEC). (1996). Public health evaluation: Cesium137 and strontium-90 in fish. Attachment to the fish consumption advisory for the Savannah River (\#3-5/14/96). Columbia, SC: SCDHEC

21. South Carolina Department of Health and Environmental Control (SCDHEC). (1999). Public health evaluation: Cesium137 and strontium-90 in fish. Columbia, SC: SCDHEC.

22. Burger, J. (1998). Fishing and risk along the Savannah River: Possible intervention. Journal of Toxicology and Environmental Health, 55, 405-419.

23. Fleming, L. E., Watkins, S., Kaderman, R., Levin, B., Ayyar, D. R., Bizzio, M., Stephens, D., \& Bean, J. A. (1995). Mercury exposure in humans through food consumption from the Everglades of Florida. Water, Air, and Soil Pollution, 80, 41-48.

24. Kvartek, E. J., Carlton, W. H., Denham, M., Eldridge, L., \& Newman, M. C. (1994). Assessment of mercury in the Savannah River Site environment (WSRC-TR-94-0218ET). Aiken, SC: Westinghouse Savannah River Company.

25. Sugg, D. W., Chesser, R. K., Brooks, J. A., \& Grasman, B. T. (1995). The association of DNA damage to concentrations of mercury and radiocesium in largemouth bass. Environmental Toxicology and Chemistry, 14, 661-668.

26. Environmental Protection Agency (EPA). (1980). Ambient water quality criteria for mercury (Report no. 440/5-80-058). Springfield, VA: National Technical Information Service.

27. Downs, S. G., Macleod, C. L., \& Lester, J. N. (1998). Mercury in precipitation and its relation to bioaccumulation in fish: $\mathrm{A}$ literature review. Water, Air, and Soil Pollution, 108, 149-187.

28. Ashley, C., \& Zeigler, C. L. (1980). Releases of radioactivity at the Savannah River Plant, 1954 through 1978 (Report DPSPU 7525-1). Aiken, SC: E. I. DuPont de Nemours and Company.

29. Whicker, F. W., Pinder, J. E., III, Bowling, J. W., Alberts, J. J., \& Brisbin, I. L., Jr. (1990). Distribution of long-lived radionuclides in an abandoned reactor cooling reservoir. Ecological Monographs, 60, 471-496.

30. Kennamer, R. A., Brisbin, I. L., Jr., McCreedy, C. D., \& Burger, J. (1998). Radiocesium in mourning doves foraging on the exposed lakebed of a contaminated reactor-cooling reser- voir: Risk to human consumers. Journal of Wildlife Management, 62, 487-508.

31. Rohde, F. C., Arndt, R. G., Lindquist, D. G., \& Parnell, J. F. (1994). Freshwater fishes of the Carolinas, Virginia, Maryland, and Delaware. Chapel Hill, NC: University of Carolina Press.

32. Bennett, D. H., \& McFarlane, R. W. (1983). The fishes of the Savannah River Plant: National environmental research park. Aiken, SC: Savannah River Ecology Laboratory.

33. Burger, J., Gaines, K. F., Boring, C. S., Stephens, W. L., Jr., Snodgrass, J., \& Gochfeld, M. (2000, December). Mercury and selenium in fish from the Savannah River: Species, trophic level and locational differences. Report from the Consortium for Risk Evaluation with Stakeholder Participation, Piscataway, NJ.

34. Jacobs, H. L., Kahn, H. D., Stralka, K. A., \& Phan, D. B. (1998). Estimates of per capita fish consumption in the U.S. based on the Continuing Survey of Food Intake by Individuals (CSFII). Risk Analysis, 18, 283-291.

35. Ruffle, B., Burmaster, D. E., Anderson, P. D., \& Gordon, H. D. (1994). Lognormal distribution for fish consumption by the general U. S. population. Risk Analysis, 14, 395-404.

36. Murray, D. M., \& Burmaster, D. E. (1994). Estimated distribution for average daily consumption of total and self-caught fish for adults in Michigan angler households. Risk Analysis, 14, 513-519.

37. Burger, J., Kennamer, R. A., Brisbin, I. L., Jr., \& Gochfeld, M. (1998). A risk assessment for consumers of mourning doves. Risk Analysis, 18, 563-573.

38. Burger, J. (2000). Gender differences in meal patterns: Role of self caught fish and wild game and meat and fish diets. Environmental Research, 83, 140-149.

39. Bakir, F., Damluji, S. F., Amin-Zaki, L., Murtadha, M., Khalidi, A., al-Rawi, N. Y., Tikriti, S., Dahahir, H. I., Clarkson, T. W., Smith, J. C., \& Doherty, R. A. (1973). Methylmercury poisoning in Iraq. Science, 181, 230-240.

40. Stern, A. H. (1993). Re-evaluation of the reference dose for methylmercury and assessment of current exposure levels. Risk Analysis, 13,355-364.

41. Agency for Toxic Substances and Disease Registry (ATSDR). (1999). Toxicologic profile for mercury. Atlanta, GA: Centers for Disease Control.

42. Davidson, P. W., Myers, G. J., \& Cox, C. (1998). Longitudinal neurodevelopmental study of Seychelles children following in utero exposure to methylmercury from maternal fish ingestion: Outcomes at 19 and 29 months. Neurotoxicology, 16, 677-688.

43. Environmental Protection Agency (EPA). (1997). Mercury study: Report to congress: Vol. 1. Executive summary (EPA452-R-97-003). Washington, DC: Author.

44. Weihe, P., Grandjean, P., Debes, F., \& White, R. (1996). Health implications for Faroe Islanders of heavy metals and PCBs from pilot whales. Science of the Total Environment, 186, 141-148.

45. Environmental Protection Agency. (1994). Guidance for assessing chemical contaminant data for use in fish advisoriesVol. 2. Risk assessment and fish consumption limits (EPA923B-94-004). Washington, DC: Office of Water, USEPA.

46. National Institute of Environmental Health Sciences (NIEHS). (1999). Scientific issues relevant to assessment of health effects from exposure to methylmercury. Triangle Park, NC: National Institute of Environmental Health Sciences. (Available at http:// www.niehs.nih.gov)

47. National Research Council. (2000). Toxicological effects of methylmercury. Washington, DC: National Academy Press.

48. Kinjo, Y., Takizawa, Y., Shibata, Y., Watanabe, M., \& Kato, H. (1995). Threshold dose for adults exposed to methylmercury in Niigata Minamata Disease outbreak. Environmental Science, 3, 91-101.

49. Ebert, E. S., Price, P. S., \& Keenan, R. E. (1994). Selection of fish consumption estimates for use in the regulatory process. 
Journal of Exposure Analysis and Environmental Epidemiology, 4, 373-393.

50. National Oceanographic Atmospheric Administration (NOAA). (1990). Fishery products inspection manual. Part III, Certification. Handbook No. 25. Washington, DC: Author.

51. Food and Drug Administration (FDA). (1987). Compliance policy guide. Washington, DC: Author.

52. DiFranco, J., \& Mower, B. (1994). Fish tissue contamination in the State of Maine-regional environmental monitoring and assessment program (REMAP). Lake and Reservoir Management, 9, 68-69.

53. Egeland, G. M., Feyk, L. A., \& Middaugh, J. P. (1998). The use of traditional foods in a healthy diet in Alaska. Alaska Epidemiology Bulletin, 2, 1-140.

54. Minnesota Department of Health. (1997). Eating Minnesota fish: Health risks and benefits. St. Paul, MN: Author.

55. Ginsberg, G. L., \& Toal, B. F. (2000). Development of a singlemeal fish consumption advisory for methyl mercury. Risk Analysis, 20, 41-47.

56. Burger, J., Gaines, K. F., Peles, J. D., Stephens, W. L., Jr., Boring, C. S., Brisbin, I. L., Jr., Snodgrass, J., Bryan, A. L., Jr., Smith, M. H., \& Gochfeld, M. (2001). Radiocesium in fish from the Savannah River and Steel Creek: Potential food chain exposure to the public. Risk Analysis, 21, 545-558.

57. Harris, S. G., \& Harper, B. L. (1998). Native American exposure scenarios and a tribal risk model. Risk Analysis, 17, 789795 .

58. Burger, J. (1999). American Indians, hunting and fishing rates, risk and the Idaho National Engineering and Environmental Laboratory. Environmental Research, 80,317-329.

59. Burger, J., Pflugh, K. K., Lurig, L., Von Hagen, L. A., \& Von Hagen, S. (1999). Fishing in urban New Jersey: Ethnicity affects information sources, perception, and compliance. Risk Analysis, 19, 217-229.

60. Patterson, B. H., Harlan, L. C., Block, G., \& Kahle, L. (1995). Food choices of whites, blacks, and hispanics: Data from the 1987 National Health Interview Survey. Nutrition and Cancer, $23,105-119$

61. Ponce, R. A., Bartell, S. M., Wong, E. Y., LaFlamme, D., Carrington, C., Lee, R. C., Patrick, D. L., Faustman, E. M., \& Bolger, M. (2000). Use of quality-adjusted life year weights with dose-response models for public health decisions: A case study of the risks and benefits of fish consumption. Risk Analysis, 20,529-542.

62. Rissanen, T., Voutilainen, S., Nyyssonen, K., Lakka, T. A., \& Salonen, J. T. (2000). Fish oil-derived fatty acids, docosahexaenoic acid and docosapentaenoic acid, and the risk of acute coronary events: The Kuopio Ischaemic Heart Disease Risk Factor Study. Circulation, 102, 2677-2679.

63. Food and Drug Administration (FDA). (1995). Mercury in fish: Cause for concern. http://vm.cfsan.fda.gov/ dms/ mercury.html (19 June 2001).

64. Morgan, J. S., Berry, M. R., \& Graves, R. L. (1997). Effects of commonly used cooking practices on total mercury concentration in fish and their impact on exposure assessments. Journal of Exposure Analysis and Environmental Epidemiology, 7, 119-134.

65. Lowe, T. P., May, T. W., Brumbaugh, W. G., \& Kane, D. A.
(1985). National contaminant biomonitoring program: Concentrations of seven elements in freshwater fish, 1978-1981. Archives of Environmental Contamination and Toxicology, 14, 363-388.

66. Lange, T. R., Royals, H. E., \& Connor, L. L. (1994). Mercury accumulation in largemouth bass (Micropterus salmoides) in a Florida lake. Archives of Environmental Contamination and Toxicology, 27, 466-471.

67. Minnesota Department of Health. (1997). Methylmercury in fish. St. Paul, Minnesota: Author.

68. Knuth, B. A. (1995). Fish consumption health advisories: Who heeds the advice. Great Lakes Research Review, 1, 3640.

69. Burger, J., \& Gochfeld, M. (1996). Fish advisories: Useful or difficult to interpret. Risk: Health, Environment, and Safety, 7, $23-33$.

70. Gochfeld, M. (1980). Tissue distribution of mercury in normal and abnormal young Common Terns. Marine Pollution Bulletin, 11,362-377.

71. Bemis, J. C., \& Seegal, R. F. (1999). Polychlorinated biphenyls and methymercury act synergistically to reduce rat brain dopamine content in vitro. Environmental Health Perspectives, 107, 879-885.

72. Environmental Protection Agency (USEPA Office of Water, 2001). Water quality criterion for the protection of human health: Methylmercury (EPA-823-f-01-001). Washington, DC: Author.

73. Gerstenberger, S. L., Pratt-Shelley, J., Beattie, M. S., \& Dellinger, J. A. (1993). Mercury concentrations of walleye (Stizostedion viteum viteum) in 34 Wisconsin lakes. Bulletin of Environmental Contamination and Toxicology, 50, 612-617.

74. Dellinger, J., Malek, L., \& Beattie, M. (1994). Mercury contamination of fish in the Ojibwa diet. 2. Sensory evoked responses in rats fed walleye. Water, Air, \& Soil Pollution, 80, 77-83.

75. Denton, G. R. W., \& Burdon-Jones, C. (1996). Trace metals in fish from the Great Barrier Reef. Marine Pollution Bulletin, 17,210-209.

76. Nakagawa, R., Yumita, Y., \& Hiromoto, M. (1997). Total mercury intake from fish and shellfish by Japanese people. Chemosphere, 35, 2909-2913.

77. Schuhmacher, M., Batiste, J., Bosque, M. A., Domingo, J. L., \& Corbella, J. (1994). Mercury concentrations in marine species from the coastal area of Tarragona Province, Spain. Dietary intake of mercury through fish and seafood consumption. Science of the Total Environment, 156, 269-273.

78. Hylander, L. D., Silva, E. C., Oliveira, L. J., Silva, S. A., Kuntze, E. K., \& Silva, D. X. (1994). Mercury levels in Alto Pantanal: A screening study. Ambio, 33, 478-484.

79. Collings, S. E., Johnson, M. S., \& Leah, R. T. (1996). Metal contamination of angler-caught fish from the Mersey Estuary. Marine Environmental Research, 41, 281-297.

80. U.S. Environmental Protection Agency (USEPA). (1995, May). Oral reference dose for methylmercury. IRIS (Integrated Risk Information Service). http://www.epa.gov/iris/ subst/0073.htm (19 June 2001).

81. World Health Organization (WHO). (1990). Methylmercury (Vol. 101). Geneva, Switzerland: WHO, International Programme on Chemical Safety. 